International Journal of Critical Indigenous Studies

\author{
Volume 8, Number 2, 2015
}

\title{
Aboriginal performance as war by other means in the nineteenth century
}

\section{Author \\ Associate Professor Maryrose Casey \\ Monash University}

\section{Abstract}

Commercial performances for entertainment are usually assumed to be lightweight, cultural activities that serve little or no serious purpose. Perhaps because of this typical perspective, prior to the mid-twentieth century, Indigenous Australian performances drawing on their cultural practices for entertainment are often styled as either the result of oppressive exploitation by colonisers or cultural tourism. However, an examination of Indigenous Australian initiated and controlled performances, for entertainment in the nineteenth century, reveals a more complicated picture.

In Australia, across the nineteenth century and well into the twentieth, Aboriginal people and the colonisers actively fought for physical, psychological and emotional sovereignty of the land through thousands of performances for entertainment purposes. This might be expected given that Australian Aboriginal cultures are probably the most performance-based in the world-in the sense that explicit, choreographed performances were used for a vast range of social and cultural purposes from education, through to spiritual practices, arranging marriage alliances, to judicial and diplomatic functions. What might be less expected, considering the dominant power position, are the multiple ways in which the white audiences attempted to intrude, interrupt and inhabit these performances. The Aboriginal performers displayed their strength, vitality, high status and continued survival literally in the face of the colonisers and charged them a fee to observe. In response, white audiences both desired these performances and acted in ways to prevent them, often taking over the performance space and bringing events to a quick finish, while complaining that the show did not go on.

The battle continued in white performances of Aboriginal practices and the ways in which Aboriginal performance was documented. In the twenty-first century, Aboriginal sportsmen who display their pride in their Aboriginality and opposition to racism continue to negotiate the same fight for space.

\section{Keywords}

Performance, resistance, colonisation, white possession. 
Since the late eighteenth century, Indigenous initiated performances, drawing on Aboriginal entertainment traditions, have played an important part of cross-cultural exchange in Australia (Casey 2011). ${ }^{1}$ In this article, developing on previous explorations of the dynamics at play between Aboriginal performers and white audiences across the nineteenth century, I seek to reveal the ways in which these embodied encounters between the colonised and the coloniser act as a form of war by other means (Casey $2013 b ; 2013 c)$. Although undeclared, this war was engaged in by both sides, the Aboriginal performers and the white audiences. To lay the groundwork for this, first I will outline the types of fun performances that were presented by Aboriginal people to white audiences for a commercial return, drawing attention to how these were interventions into the physical and social landscape that asserted Aboriginal sovereignty and survival in the face of colonisation. Then I outline the ways in which white audiences responded, particularly when the performance area was a symbolic space, such as cricket grounds and football ovals; responses that have direct parallels with the responses to Adam Goodes in 2015.

I argue that the white responses to these performances demonstrate an aggressive investment in the racialised justifications for dispossession and war against Aboriginal people, in the Australian colonies, by the white colonists. This investment leads to an ongoing war by any means at any time to defend any challenge to white possession and dominance. In Society must be Defended, Michel Foucault $(2003,15)$ turned Clausewitz's famous axiom on its head, arguing that politics in the form of government and state practices is a form of war by other means. Foucault argues that

power is ... the implementation and deployment of a relationship of force ... the role of political power is perpetually to use a sort of silent war to reinscribe that relationship of force, and to reinscribe it ... even on the bodies of individuals. (15-16)

As Aileen Moreton-Robinson has persuasively argued, drawing on and extending Foucault's work, colonisation in Australia was a "race war of coercion, murder, and appropriation" $(2015,157)$. Central to this are the practices that she has revealed of white patriarchal possession, where land and Indigenous peoples are culturally and socially constructed as possessions, with the attribution and assumptions of the authority and power that ownership implies.

To ensure this dominion, the colonisers relied on an active and overt deployment of force at every official level. They also relied on, and continue to rely on, other subtle forms of force that operate at the grass-roots levels of communities, as people in the streets and audiences, for local performances and at sporting events.

The focus of this paper is on what happens when the people framed as possessions refuse to co-operate and insist on constructing their own identities and ontologies and assert their authority, not only in the past, but also in the present.

In the twentieth century, Gerry Bostock and Jack Davis both argued that Aboriginal theatre was a political intervention, because it presented contemporary, Aboriginal life (Bostock quoted in Watego 1987, 71; Davis 1984, 46). In the nineteenth century, the physical presence of the living Aboriginal performer in control of him or herself and their actions was also an intervention in the social and political context of the European colonies. At a time when the removal and violent erasure of Aboriginal people was a widely accepted 
and intrinsic part of narratives of colonialism and white superiority, the active presence of Aboriginal people demonstrating their sovereignty and cultural and physical vitality is implicitly and explicitly a challenge that reveals the local geopolitics and "body-politics" in a clear gesture to white audiences of "epistemic disobedience" (Mignolo 2009, 172).

After European colonisation, Indigenous communities extended their public performance practices to incorporate European visitors and settlers as part of the audience (Casey 2012a, 49-50). These performances, presented on a commercial basis for entertainment within the cross-cultural context, are often represented as cultural tourism (Bruce and Calloway 1991, 96; Parsons 2002, 14; 1997, 46). From the 1890s, there were performances for visiting steamships on tourist routes that fit within this category (Notes of the Week 1893, 2). However, there were also a broad range of performances across the nineteenth and into the twentieth centuries that do not fit. In the latter, audiences were not tourists, they were settlers; people who were actively seeking to exclude Aboriginal people from the developing nation. ${ }^{2}$

The performances under discussion were not for ceremony, but public performances designed for entertainment. Traditionally, Aboriginal performances for entertainment were created around topical themes, events and observations. These were performed for intraand inter-community gatherings. There are hundreds of genres of performance for entertainment across the many Aboriginal communities around the country. The available information from the records of colonists, settlers, visitors and ethnographers suggests that a range of performance genres were common across the country, probably due to the centuries of trading performances across the continent. These are usually comedic, narrative-based shows and incorporate song, poetry, dance, costume, props and dialogue. In this article, I am using the word 'corroboree' as a general term for these performances.

There are thousands of accounts of performances for fun. From early in the nineteenth century, Aboriginal people charged white audiences to watch them. The size of the white audience varies from two or three to tens of thousands. In general, when corroboree performances were presented to large scale, white audiences, they usually consisted of a program containing a range of discrete segments, some short and some longer. For example, the Grand Corroboree, performed in 1885 at the Adelaide Oval, was divided into four parts, including a narrative about hunting kangaroos, a satire about white civilisation teaching the audience the values of temperance, and a 'saltwater dance' from the Yorke Peninsula (Saturday Night's Corroboree 1885, 6; The Corroboree 1885, 6). The performance also included a mock battle (Aboriginal Corroboree at Adelaide 1885, 9). Other programs consisted of a single narrative. In 1847, a group of Aboriginal people from Amity Point on Stradbroke Island in Queensland performed on the mainland at Kangaroo Point in Brisbane, "a dramatic representation descriptive of the wreck of the Sovereign steamer" (The Blacks 1847, 2). The Sovereign, a passenger and cargo ship, had been wrecked off the coast of Stradbroke Island the previous March. Six Quandamooka men risked their lives swimming out, in rough seas and extreme conditions, to bring people to shore. The 10 who they managed to rescue were the only survivors of the $54 \mathrm{crew}$ and passengers on board. The performance was described as being "highly expressive of that unfortunate event".

The genre of performance most in demand by white audiences were those that consisted of mock battles or war dances (Casey 2012b). These performances, based on judicial practices that some Aboriginal people called 'dangerous dances', were part of traditional entertainment and training for warriors. Aboriginal judicial practices operated within a system of partial duel and partial trial by ordeal (Buckley 1852, 3; Petrie 1902, 1403; 
Warner 1937, 174-176). The dangerous dances were an opportunity for young men to demonstrate their prowess and, at the same time, to build their skills. The usual format was that the opposing combatants would dance up to each other and then back. The spearing or, in the case of dangerous dancers, objects and weapons, would be thrown at each other and then there would be a final dance acknowledging resolution. The demand by white people to see these performances was marked from the first settlements (Casey 2012b).

\section{Asserting Sovereignty and Claiming Space}

For Aboriginal people, performances that were presented as events for cross-cultural audiences served a range of functions. These included political and diplomatic purposes; a basis for cross-cultural communication; asserting sovereignty over the land; educating non-Indigenous settlers about Indigenous cultures; entertainment; and enabling Indigenous Australians to earn money and engage with the settler economy (Casey 2012a). These performances were generally created first and foremost for Aboriginal communities and performed in country. ${ }^{3}$ Following traditional practices of barter and exchange in relation to these types of performances, the commercial aspect was a minor adaptation. Among the key features at play in Aboriginal-controlled performances are that no changes were made for white audiences except for playful elements, such as including mimicry of specific white people in the audience, if they were known to the performers and, sometimes, a sharpening of the political point of the performance.

In one account, identified by the journalist as a "dramatic corroboree" (Australian Aborigines 1914, 5), the narrative begins with three Chinese men fighting over a gun.

The manners of the imaginary disputants and their labial language sounds were introduced with inimitable fidelity. Stealthily the tribesmen [Aboriginal warriors] crept through the long grass upon the noisy Celestials, and their approach vividly reminded me of a cat stalking with tense muscles and deadly intentness the ball of paper it was given which it was pleased to pretend was a bird. The attack when made was certainly feline in its overwhelming suddenness, and the slaying done, the tribesmen crept back into the bush carrying the stolen gun.

Later came some police troopers blundering upon the scene. These examined with much detail and portentous solemnity the murdered Chinamen. The sibilant sounds of the English language ... were copied with equal fidelity by the players. But an unexpected finale was reached when the Celestials proved not to be dead at all. Instead they sprung up, overturned the policemen, and ran away howling into the darkness. (Australian Aborigines 1914, 5)

The writer went on to tell of a later dance that incorporated "a somewhat ridiculous incident connected" with his own arrival by boat including his "manner of walking" and his voice. He suffered the discomfort of seeing his own mannerisms and actions copied with "laughable faithfulness" (Australian Aborigines 1914, 5).

Regardless of the content, the songs and texts were not translated from Aboriginal languages, nor were the meanings of performances explained, nor the content modified for the white audiences. This is true of performances in all of the different genres, including comedies that satirised colonisation and the colonisers (Casey 2013b). Within the framework of Aboriginal practices, the performances in Aboriginal languages without explanation were an offer of knowledge to the settlers that required them to actively 
engage and learn. At the same time, this use of Language directly confronted the colonial dismissals of Indigenous languages and attempts to eradicate them.

The assertion of the strength and knowledges of Aboriginal people was also deployed on other levels within the performances. In Aboriginal cultures, the dancing body demonstrates and represents vitality as well as important skills and prowess. Within Aboriginal contexts, virtuosity and knowledge grant status. The Aboriginal performers displayed their strength, vitality, high status and continued survival literally in the face of the colonisers, and charged them for it. The performances also actively claimed public space for Aboriginal people within the new society and the nation that was being formed.

\section{Negotiating Responses}

The responses of white audiences to these performances were complicated and, at times, conflicted. For the white audiences, there is the desire to witness corroborees that was consistently demonstrated (Casey 2012a). There are lots of reasons for this, including the desire to view people who are framed as exotic or primitive. Implicit in this position or relationship to the performances are the notions of cultural hierarchies intrinsic to the colonial enterprise and the resulting claiming of power in relation to the performers.

The assertion of ownership of events and control of the Aboriginal performers is demonstrated by numerous examples. The performances are consistently framed as childish or meaningless acts in a context where many observers admit to complete ignorance of the purpose or meaning of them (Westgarth 1848, 78). There is a lack of respect for the performers and the performance on multiple levels. An indicative example of attitudes towards Aboriginal performances is revealed in an account from 1879. Some settlers attended a performance for entertainment in Queensland that included a sequence where:

... 100 blacks assembled around a tree and commenced ascending until there was about thirty of them up the trunk. I remarked that it was cut off about $40 \mathrm{ft}$ from the ground, and they crowded up till the tree could hold no more, with one of them on top. A large number of them had a grotesque head-dress, with an arched bow from the back of the head, with cockatoos' crests placed in sticks standing straight up. On a song being given by those below, the men in the tree would all swing around half way at arm's length, bowing their heads feathers and all, and then back again. (Logan and Albert 1879,6)

One of the settlers became convinced that, in order to achieve the movements the performers were making, the tree must be "worked round in a groove" (Logan and Albert $1879,6)$, so they struck matches and walked up to the tree in the middle of the performance to see if they were right. Needless to say, the performers responded angrily to the interruption and made the white men put out their matches and retire from the performing space. In that situation, those two men were the only white people present, so their disrespect was for the Aboriginal performers and audience.

Another part of the dynamic is a resistance to paying Aboriginal performers in advance. If they had the opportunity, white audiences would generally insist on giving money as they thought appropriate at the end of the performance. There were also problems with members of audiences who preferred not to pay at all. In one example, a member of the audience "while an aboriginal was making a collection, [after the performance] a man ... knocked the hat out of his hand, scattering the money already collected in the dust" 
(Booligal 1878, 2). Another issue in relation to numerous Aboriginal performances are incidents where white people 'gate-crashed' large events, when money was collected before the performance, such as the Grand Corroboree in Adelaide in 1885 (Casey 2011). Aboriginal performers negotiated these problems in a range of ways, from passing around the hat before each sequence, to fencing off a paddock with "a wall of saplings and gumtree branches" that was "very thoroughly done, and even the most inquisitive ... could not get a comfortable squint through" (Dubbo 1891, 1; Jottings by the way 1896, 299). No-one was admitted to that performance unless they paid "a silver coin" (At Poverty Point 1896, 9).

There is clearly a lack of respect shown for the performers in a range of ways, but the assertion of the white man's power in the situation went further than this. It is these types of behaviours that, I suggest, are explicitly aggressive and an act of war to claim possession of the land in both physical and symbolic ways. These examples of adjustments to control the audience draw attention to additional challenges, in particular, the white audience moving into the performance space and effectively preventing the performance from going ahead until they are removed. Physically crowding the performance space was often done when the performance was in a football or cricket ground, the audience had paid for their tickets and had grand stand seating. The audience would leave their seats and physically take over the performance space, often preventing the event from starting, let alone continuing. So, the white audience arrives, eager to watch the show, then prevents it going forward in a battle for what?

The incidents that I am drawing attention to are not ones where a group of people overtly or aggressively want to prevent a performance. There are examples of people setting out to stop performances in this way. In 1898, there was an incident that was widely reported in the press under headings such as "An Attack on the Blacks", "Interrupted Corroboree", and "Broken Hill Frightened Blacks" (An Attack on the Blacks 1898, 5; An Interrupted Corroboree 1898, 3; Broken Hill: Frightened Blacks 1898, 5).

A group of young, white men variously called 'scamps' or 'larrikins' started throwing stones at a group of Aboriginal men who were performing within the town of Broken Hill, New South Wales (NSW). The Aboriginal men tried to withdraw to safety, but the white crowd, which grew to 200, chased them for more than two miles on foot and in carriages. The police eventually dispersed the 'mob'. The Aboriginal men then returned to the original site and gave their performance. According to one report, the larrikins said, "it was all for fun" (An Attack on the Blacks 1898, 5). A significant aspect of this event is that, after being harangued, stoned and chased for miles, the Aboriginal men went back to the starting point and gave their performance. The performance was commercial and for a white audience, not a performance for ceremony (An Attack on the Blacks 1898, 5). The Indigenous men had announced that they were seeking to earn money to help them subsist through the winter. Their previous attempt had resulted in, what amounted to, a riot, involving at least 200 people racing through the streets of a small country town just a short time earlier. Yet, as soon as the Indigenous men could, during the same afternoon, they resumed their intention to perform. This might indicate a determination or need to earn money, but it is suggestive of more than this. It indicates a determination to claim the right to be in the space by the Aboriginal men and that the performances served a more complicated purpose than just making money.

Most incidents where the audience crowded out the performers follow a similar pattern (though other incidents are not examples of when a group wishes to harass the performers or stop the performance.) One example, which I have discussed previously, is the Grand 
Corroboree performed in 1885 at the Adelaide Oval (Casey 2011). On the first night the audience was estimated at around 20,000. The performance area was in front of the main stand. Surrounded by metal hurdles, there were large camp fires lit within the defined space. After the Aboriginal women came out, placed themselves and began singing, the audience began moving forward, knocking over the metal barrier and crowding the whole performance space, so that the performers had to retreat from the space completely. One Aboriginal performer was quoted as describing the resulting chaos as a "white fellow's corroboree" (Aboriginal Corrobboree (sic) 1885, 6). Once the police had restored order, the performers proceeded with the show (The Corroboree 1885, 6). There are examples of this type of crowding across the country. These include a performance in the Gun Club grounds, Osborne in Western Australia (A Corroboree 1898, 27) and a performance in Melbourne in 1897 (Argus 1897, 4). Accounts of the Melbourne performance in Richmond describe how "the encircling ring [of the audience] began to contract, and children cried and women screamed as the surging mass pressed closer" (Argus 1897, 4). The Aboriginal performers retreated until it was safe to return. In 1899, there was an exhibition performance put on for the visiting British rugby team in Brisbane. One of the British visitors described the crowding of the field by the audience. The performance did not go on until two hours later than expected, when half of the audience had left (Jarman 1899, 34). There are other accounts that mention members of the audience surrounding the performers when they were preparing for the performance (Anniversary Day 1893, 2).

Given racialised narratives and the license that the biopower, claimed by colonial governments, granted to privileged white citizens, it is to be expected that white people would act in a way that asserts that they are in control of the performance, its content, length and the level of remuneration due at the end. However, that they will go as far as to stop a performance that they have come to see and paid for, and then complain goes beyond that.

These performances have a number of commonalities. One is that they are Aboriginalcontrolled. Another is the numbers of people involved. The groups of Aboriginal performers are usually in the hundreds and white audiences in the thousands. A third commonality is that the events largely happened in sporting arenas, cricket and football grounds with barriers established to claim the performance space. This type of crowding appears, from my research so far, to have begun, or at least become more noticeable, at much the same time as the rise of Australian nationalism and the so-called 'native born', white Australians began to assert themselves politically, especially in the 1880 s to 1890 s, as typified by the Bulletin (Chester and Galligan 1997, 87-88). These types of incidents continue into the first decades of the twentieth century. They did not happen when the events were initiated by white entrepreneurs, presenting performances by Aboriginal people as ethnographic displays, such as Archibald Meston's tour of Wild Australia in the early 1890s.

If this behaviour is a matter of a mass of individuals all claiming ownership, needing to be in the front row so that they can see the whites of the eyes of the performers, the crowding out the performance space, no matter how well it is marked out, is not sensible behaviour. It also consistently happens before the show starts, as the first performers, usually women, take their places, so it is not a matter of jostling for a better position because people cannot see. For the same reason, it is not equivalent to 'pitch invasions' as they developed over the twentieth century. Those types of invasion usually occur after a game, either as a protest or celebration.

The events that I am referring to, where the performance space was overrun, had almost exclusively white audiences. So, the disrespect is not just for the Aboriginal performers, 
but also for their fellow white audience members on a large scale. There is no hint in any of these accounts that the crowding out of the performers is aimed at attacking the Aboriginal people or preventing the performance. Some of the accounts come from visiting sportsmen from other countries, who could only express shock at the behaviour, with no idea of why it was done. Paul Dwyer has suggested that the issue may, in fact, have been inflected by class-based tensions between members of the audience. ${ }^{4}$ This may well be an aspect of the dynamics. If it is, it suggests that the sense of possession of Aboriginal people and domination crossed class boundaries, rather than there being a sense of shared issues between lower class Euro-Australians and Aboriginal people. In one incident, when the crowd overran the performance space, some white members of the public brought their carriages onto the pitch. This approach is reminiscent of boxing events in the early nineteenth century, when such events were illegal, and crowds 'in the know' gathered at the appointed place, with the upper classes in their carriages and the lower classes on the ground. These possibilities make it clear that there are differences within the crowd, but the result, in relation to the Aboriginal performers, is the same, although perhaps exacerbated by the ways in which the different groupings within the white audiences compete to claim ownership and control. Added to this, in press reports, there is no recognition that the Aboriginal people might be affected by this behaviour. The only problem that is acknowledged is the audience's enjoyment or lack of it because of the encroachment onto the performance space. The unrestrained exercise of the audience's desire to have a good view indicates a widespread acceptance of a particular performativity of whiteness in relation to Indigenous performance. However, more than this, the behaviour, as an act of white possession, raises questions.

In the above incidents, the need to assert physical and spatial ownership or dominance overrides everything else, including the ways in which audience members are representing the white population in front of visitors from the imperial centre. This choice suggests a more complicated desire on the part of the audience in relation to the performances than just watching performers. If the sense of white possession was comfortable and assured, presumably the Euro-Australian audience would have presented themselves as generously patronising the Aboriginal 'remnants'. It is the need to assert who is in control that leads me to interpret these incidents as a continuing show of force on a basic level within the colonial war to conquer Aboriginal people. Myths about dying races and the inferiority of those set aside as inferior races are, as David Macey $(2009,195)$ points, out "rarely troubled by the empirical", but these actions suggest that those who subscribe to theories in Australia can be bothered in practice.

Sara Ahmed $(2007,150)$ argues that the phenomenology of whiteness "orientates bodies in specific directions, affecting how they 'take up' space" and as "an effect of racialization ... shapes what it is that bodies 'can do'". She goes on to state that:

'Doing things' depends not so much on intrinsic capacity, or even dispositions or habits, but on the ways in which the world is available as a space for action, a space where things 'have a certain place' or are in place, (Ahmed 2007, 153)

Implicit in this perceptual framework is also the corollary that limits how excluded bodies take up space or what they can do and their place. These issues of the right to take up space and action are central to the Aboriginal determination to perform in the crosscultural context and the conflicted response of the white audiences.

An important myth within the colonial enterprise in Australia is the absence of Aboriginal people in the contemporaneous moment. This myth of absence was quickly established 
after settlement in the late eighteenth century (Casey 2012b). In terms of the performances under discussion, the denial of the embodied Aboriginal presence on a dayto-day basis is consistently reproduced in the reportage. No matter how often these performances are discussed, they are regularly, over the nineteenth century, described in the newspapers as 'unique', 'novel' or something that has not been seen for decades (Native Corroboree 1898, 6; The Corroboree 1884, 3; The Eucalyptus Corroboree $1892,1)$. This insistence on the novelty of Aboriginal presence is, in effect, a denial of proximity and co-existence (Casey 2012b). At the same time, numerous types of performances are noted or described that are not so easily treated as displays of a fading race. In 1892, the Aboriginal people employed at the Duaringa Eucalyptus Works went on strike over a cut in their pay rates. As part of their protest:

On Saturday evening the entire tribe ... came marching in procession into Duaringa carrying an effigy of Uncle Tom (the boss of the job), which was every now and then hooted at in the most approved fashion. Afterwards they returned to their camp and held a grand corroboree, and at the close, amid the most frightful yells of exultation, burned the effigy of Uncle Tom. (Smoke-Ho 1892, 3)

There are also numerous comedic performances documented that parodied white people. In the 1930s, these included a 'command' performance created for a group of big game hunters in the Northern Territory (Wildlife teams at Mary River 1931, 14). The game hunters insisted that the Aboriginal people who had acted as their guides perform a corroboree for them. In response to the demand, the guides created a work based on their observations of the hunters in an incident that did not show them to advantage:

Painted and wearing only loin-cloths, they staged by the fireside a comical presentation of members of the expedition buffalo shooting. They showed a callous disregard for the feelings of the members of the party who made for a tree when a buffalo bull showed signs of charging in their direction. (Wildlife teams at Mary River 1931, 14)

Despite numerous examples of performances, the myth of the erasure of Aboriginal people is incorporated into the documentation. The incidents all occur in contexts where Aboriginal people have been forcibly relocated to reserves and denied free movement within their country. However, the Aboriginal people found opportunities to effectively control symbolic white space, such as sports grounds, and the white audience was constrained by fences and barriers. In this context, I would suggest that the overrunning of the performance space was due to an unacknowledged discomfort experienced by the settler colonists when confronted by the embodied culturally-strong presence of Aboriginal people. Ahmed $(2014,160)$, in her examination of the resistance to "willful" (sic) subjects has argued that: "Just being is wilful work for those whose being is not only not supported by the general body, but deemed a threat to that body". She goes further, stating that "in asserting ourselves, we are asserting more than ourselves. If we do not submit our will to the will of the 'whole body' ... We are exposing the violence that supports that body", where the body in question is the general will of the dominant majority (Ahmed 2014, 160). Within these encounters, there are multiple layers of disturbance and challenge.

The Aboriginal people involved are asserting their existence and their strength. In doing so, these performances by Aboriginal people in Aboriginal languages, drawing on Aboriginal practices and claiming space for their living cultures, disturbed the white audiences' claimed biopower in relation to Aboriginal people, causing them to act to assert their authority and claims about the land, and the non-existence of Aboriginal people in an unconscious collective act. Ahmed's (2014) argument suggests that part of this 
disturbance is the centring of the reality of colonial violence, in contrast to comfortable myths of peaceful settlement.

There are parallels in these responses to performers in the recent events around Adam Goodes, a leading Australian Football League (AFL) player and an Adnyamathanha and Narungga man. A champion footballer and former Australian of the year, Goodes has been the focus of a campaign of incessant booing at matches over a number of months and abused extensively on social media. Goodes is proudly Aboriginal and has a record for community work particularly working for Indigenous youth and advocacy against racism.

During a match in May 2015, Goodes celebrated a goal that he scored in the Indigenous round by dancing a simple war dance he had learnt from the Flying Boomerangs, a junior Indigenous football club. The war cry was a mixture of basic elements drawn from a range of language groupings. The dance, as performed by Goodes on the field, consisted of a series of running steps and miming the action of throwing a spear. He performed the war cry, dancing towards a section of the spectators who supported the opposing team.

The aftermath of the war dance includes a level of booing that Fiona Nicoll, who has "been to many, many AFL games", says she has "never heard this kind or scale of booing. It was whenever he touched the ball" (email correspondence 2015). The violence and relentlessness of the booing has made it a topic that cannot be ignored by sports and political commentators, as well as thousands of blogs and social media sites. The booing and furore continued to escalate for months until Goodes retired from AFL football in September 2015.

The responses to the booing have been split. The Australian Football League and Goodes' club made public statements in support of him. Satirists and comedians had fun writing about the ways in which Goodes was "under fire for being flagrantly Aboriginal" and the dangers of imaginary spears that might cause imaginary wounds (Jackson 2015; Pobjie 2015; Stanford 2015). However, a conservative newspaper's poll found that $68 \%$ of their readers found the dance inappropriate (Panihi 2015a). Conservative commentators have roundly condemned Goodes, denying that there was any taint of racism in the virulent responses and boos (Booker 2015; Levy 2015). Goodes has been widely described as the one at fault. Those on this side of the debate argue that the intense hostility to Goodes is purely a dislike of him personally, not as an Aboriginal. (Devine 2015; Hamad 2015; Panahi 2015b. As part of the attacks in support of the booing, Goodes has been accused of being a 'cheat' in the football matches, trying to create a 'race war' and as having 'monstered' a child when he reported a racial attack in 2013 (Redden 2015; Trev 2015; Tropical 2015).

In many of the blogs and responses to newspaper articles, the condemnation of Goodes has been about their outrage that they did not have a choice in relation to his war cry. The suggestion has been that it is his fault and would have had a different response if the audience had been prepared or warned. One response to a newspaper article effectively equates a preliminary announcement with respect (Giftedintrovert 2015).

Central to the arguments against Goodes is the sentiment expressed in the statement "if players stop parading their identity the problem will go away" (Stanford 2015). Goodes is accused of "an intolerable act of aggression" (Hamad 2015) by forcing the spectators to witness his proudly Aboriginal celebration. Effectively Goodes represents or presents as the 'Willful' subject that Ahmed $(2014,160)$ describes. This willfulness in the face of the dominant majority produces visceral responses. 
Comments by bloggers suggest that the white audience felt that it had a lack of choice. But why should they have choice? Why do they need a warning to prepare them? It is part of Australian racism that white people have control; they are, after all, in possession. This need for control does not seem to have shifted over time. Although Aboriginal football players are no longer attacked and hospitalised by other players and fans, as Lionel Morgan was in 1960, the Aboriginal performance of proud and strong Aboriginality in the sporting arena, an important symbolic space of white Australia, continues to be too disturbing to be passively accepted. The strong Aboriginal presence continues to be perceived as epistemic disobedience that profoundly unsettles the heirs to Australian colonisation provoking active responses. The fact that the embedded sense of white possession can still be disturbed by the active, embodied Aboriginal presence suggests hope for the possibility of change.

Biography: Maryrose Casey has been published widely about Indigenous Australian performance. Her publications include Creating Frames: Contemporary Indigenous Theatre (2004), Telling Stories: Aboriginal and Torres Strait Islander Performance (2012) and Embodying Transformation: Studies in Transnational Performance (2015). She is an Australian Research Council Future Fellow at the Monash Indigenous Centre. 


\section{References}

"A Corroboree." 1898. Western Mail, 23 December, 27.

"A Corrobboree Extraordinary" (sic). 1885. South Australian Register, 30 May, 4, 5.

"A Scene in the Wild." 183). Sydney Gazette and New South Wales Advertiser, 14 May, 4.

Aboriginal Corroboree at Adelaide. 1885. Australasian Sketcher with Pen and Pencil, 29 June, 9.

"Aboriginal Corrobboree" (sic). 1885. South Australian Register, 1 June, 7.

"Aboriginal Corrobboree" (sic). 1885. South Australian Register, 30 May, 6.

Ahmed, Sara. 2007. "A Phenomenology of Whiteness." Feminist Theory, 8 (2): 149-168.

Ahmed, Sara. 2014. Willful Subjects (sic). Durham and London: Duke University Press.

"An Attack on the Blacks." 1898. West Australian, 5 May, 5.

"An Interrupted Corroboree." 1898. Barrier Miner, 4 May, 3.

"Anniversary Day." 1893. Barrier Miner, 27 January, 2.

Argus. 1897. 20 April, 4.

"At Poverty Point." 1896. The Bulletin, 14 March, 9.

"Australian Aborigines." 1914. Evelyn Observer and Burke East Record, 5.

"Broken Hill: Frightened Blacks." 1898. Advertiser, 5 May, 5.

Booker, Chloe. 2015. "Adam Goodes should admit he was wrong, says Andrew Bolt." Sydney Morning Herald, July 30.http://www.smh.com.au/entertainment/tv-and-radio/adamgoodes-should-admit-he-was-wrong-says-andrew-bolt-20150730-

gioa10.html\#ixzz3kZAK4F4q

"Booligal." 1878. Sydney Morning Herald, 14 January, 2.

Bruce, Candice and Anita Callaway. 1991. "Dancing in the Dark: Black Corroboree or White Spectacle." Australian and New Zealand Journal of Art, 9 (1): 78-104.

Buckley, William. 1852. "Review: The Life and Adventures of William Buckley." Colonial Times (Hobart, Tasmania), 7 May, 3.

Casey, Maryrose. 2011. "Cross-Cultural Encounters: Aboriginal Performers and European Audiences in the Late 1800s and Early 1900s." Double Dialogues, 14. Accessed 10/8/15. http://www.doubledialogues.com/article/cross-cultural-encounters-aboriginal-performersand-european-audiences-in-the-late-1800s-and-early-1900s/

Casey, Maryrose. 2012a. Telling Stories: Aboriginal and Torres Strait Islander Performance. Melbourne: Australian Scholarly Publishing.

Casey, Maryrose. 2012b. "Colonisation, Notions of Authenticity and Aboriginal Australian Performance." Critical Race and Whiteness Studies. Accessed on 10/8/15. http://www.acrawsa.org.au/files/ejournalfiles/177CRWS201281X.pdf

Casey, Maryrose. 2013a. "Making fun of trauma: Laughing at racialised violence." Performing Ethos: International Journal of Ethics in Theatre and Performance, 4 (1): 9-23.

Casey, Maryrose. 2013b. "Conditions of Recognition: Social aesthetics and Aboriginal Australian performance." Aesthetics, 23 (1): 92-109.

Casey, Maryrose. 2013c. "Colonists, settlers and Aboriginal Australian war cries: Cultural Performance and Economic Exchange." Performance Research, 18 (3): 56-66. 
Chesterman, John, \& Brian Galligan. 1997. Citizens Without Rights. Cambridge: Cambridge University Press.

Davis, Jack. 1984. "The Dreamers Interview.” Meanjin. 43 (1):46-48..

Devine, Miranda. 2015. "Adam Goodes Isn't Booed for the Colour of His Skin. He Is Booed for Acting Like a Pillock." Daily Telegraph. 17 June. Accessed on 10/8/2015. http://www.dailytelegraph.com.au/rendezview/adam-goodes-isnt-booed-for-the-colour-ofhis-skin-he-is-booed-for-acting-like-a-pillock/story-fnpug1jf-1227401141399

“Dubbo." 1891. Maitland Mercury \& Hunter River Advertiser, 26 September, 1.

Foucault, Michel. 2003. "Society must be Defended: Lectures at the College de France 1975-1978." Translated by Graham Burchell. London: Palgrave Macmillan.

GiftedIntrovert whobroughtoranges. "Comments." Accessed 1/8/2015. http://www.theguardian.com/sport/blog/2015/jul/29/afl-great-adam-goodes-is-being-booedacross-australia-how-did-it-come-to-this

Hamad, Ruby. 2015. "The Real Reason People Are Outraged over Adam Goodes' 'War Dance'." Daily Life. 1 June. Accessed on 30 July 2015. http://www.dailylife.com.au/newsand-views/dl-opinion/the-real-reason-people-are-outraged-over-adam-goodes-war-dance20150601-ghdt84.html

Jackson, Russell. 2015. "Adam Goodes: Why His Critics' Arguments Just Don't Stack Up.”. The Guardian. 28 July. 1/8/2015. http://www.theguardian.com/sport/blog/2015/jul/28/adam-goodes-why-his-criticsarguments-just-dont-stack-up

Jarman, Wallace. 1899. "The British Football Team." Morning Bulletin, 27 October, 5.

"Jottings by the way." 1896. The Queenslander, 15 Feb, 299.

Levy, Megan. 2015. "Swans star Adam Goodes always plays the victim: Alan Jones." Sydney Morning Herald, July 29. Accessed 1/8/2015. http://www.smh.com.au/afl/sydneyswans/swans-star-adam-goodes-always-plays-the-victim-alan-jones-20150728gimmn3.html\#ixzz3kZBMpSFf

"Logan and Albert." 1879. Brisbane Courier, 15 March, 6.

Macey, David. 2009. "Rethinking Biopolitics, Race and Power in the Wake of Foucault". Theory, Culture and Society. 26, (6): 186-205.

Mignolo, Walter D. 2009. "Epistemic Disobedience, Independent Thought and Decolonial Freedom". Theory, Culture and Society. 26, (7-8): 159-181.

Moreton-Robinson, Aileen. 2015. The White Possessive: Property, Power and Indigenous Sovereignty. Minneapolis: Minnesota Press.

"Native Corroboree." 1898. The Advertiser, 31 January, 6.

"Notes of the Week." 1893. Northern Territory Times and Gazette, 21 July, 2.

Panahi, Rita. 2015a. "The Goodes Debate: Who Is Right." Herald Sun, July 30. Accessed 1/8/2015. http:// www.heraldsun.com.au/news/victoria/is-booing-adam-goodes-racistjournalists-rita-panahi-warwick-green-debate-the-issue/news-

story/cf040e09309b6ef65da75cc2d7381cae?from=public_rss\&memtype=anonymous

Panahi, Rita. 2015b. "The Goodes, the Bad and the Ugly." Herald Sun, July 29. Accessed 1/8/2015. http://www.heraldsun.com.au/news/opinion/the-goodes-the-bad-and-theugly/story-fniOfhh1-1227460762592 
Parsons, Michael. 1997. "The Tourist Corroboree in South Australia." Aboriginal History, 2: 46-68.

Parsons, Michael. 2002. "Ah that I could convey a proper idea of this interesting wild play of the natives." Australian Aboriginal Studies, 2: 14-26.

Petrie, Tom. 1904. Reminiscences of Early Queensland. Edited by Constance Petrie (dating from 1837). Brisbane: Watson Ferguson.

Pobjie, Ben. 2015. "So Adam Goodes, Who Is the Real Racist?" The Roar. 2 June. Accessed on 1/8/2015. http://www.theroar.com.au/2015/06/02/adam-goodes-real-racist/

Redden. $28 \mathrm{Jul} 2015 . \quad$ "Comments." Accessed 1/8/2015. http://www.dailytelegraph.com.au/rendezview/adam-goodes-isnt-booed-for-the-colour-ofhis-skin-he-is-booed-for-acting-like-a-pillock/story-fnpug1jf-1227401141399

"Saturday Night's Corroboree." 1885. South Australian Advertiser, 3 June, 5.

"Smoke-Ho." 1892. Worker, 27 August, 3.

Stanford, Jeemy. 2015. "Booing Adam Goodes: are we even aware we're racists?" 28 July. Accessed 1/8/2015. http://www.abc.net.au/news/2015-07-28/standford-booing-adamgoodes:-are-we-even-aware-we're-racists/6653108

"The Blacks." 1847. Moreton Bay Courier, 19 June, 2.

"The Corroboree." 1884. Camperdown Chronicle, 14 May, 3.

"The Corroboree." 1885. South Australian Advertiser, 30 May, 6.

“The Eucalyptus Corroboree.” 1892. Morning Bulletin, 8 July, 1.

Trev. 28 Jul 2015. "Comments." Accessed 1/8/2015. http://www.abc.net.au/news/2015-0728/standford-booing-adam-goodes-are-we-even-aware-were-racists/6653108

Tropical. 28 Jul 2015. "Comments." Accessed 1/8/2015. http://www.abc.net.au/news/201507-28/standford-booing-adam-goodes-are-we-even-aware-were-racists/6653108

Warner, William Lloyd. 1937. A Black civilization: A social study of an Australian Tribe. New York: Harper and Brothers.

Watego, Cliff. 1987. "Aboriginal Dramatists' in Community Theatre in Australia." Edited by Richard Fotheringham. Sydney: Methuen.

Westgarth, William. 1848. Australia Felix, or A historical and descriptive account of the settlement of Port Phillip, New South Wales : including full particulars of the manners and customs of the Aboriginal native. Edinburgh: Oliver \& Boyd.

"Wildlife Teems at Mary River: Great Sport for Big Game Expedition." 1931. Advertiser and Register (Adelaide), 11 July, 14.

\footnotetext{
${ }^{1}$ I would like to thank the blind referees and editors for their generous feedback and helpful suggestions.

${ }^{2}$ I am indebted to Aileen Moreton-Robinson for articulating this aspect.

${ }^{3}$ Aboriginal Australian people refer to their traditional homelands as their 'country'. 'In country' means within their homelands.

${ }^{4}$ I would like to acknowledge and thank Paul Dwyer, who raised this line of argument when I presented an early version of this paper at the ADSA Conference in Wellington in 2014.
} 